\section{Evaluation of compliance to local guidelines for risk factor based screening for gestational diabetes mellitus in Trebinje and Belgrade}

\author{
Danijela Popadic ${ }^{1}$, Miroslava Gojnic Dugalic ${ }^{2,3}$, Milan \\ Perovic $^{4,5}$, Bojana Gutic ${ }^{2}$, Tomislav Stefanovic ${ }^{5}$, Milica \\ Kovacevic ${ }^{5}$, Svetlana Popovac ${ }^{4}$, Jovana Radakovic ${ }^{4}$, Uros Babic ${ }^{6}$ \\ ${ }^{1}$ Department for Gynecology and Obstetrics, General Hospital of \\ Trebinje, Trebinje, Bosnia and Herzegovina \\ ${ }^{2}$ Clinic for Gynecology and Obstetrics, Clinical center of Serbia, \\ Belgrade, Serbia \\ ${ }^{3}$ University of Belgrade, Faculty of Medicine \\ ${ }^{4}$ Clinic for Gynecology and Obstetrics "Narodni front", Belgrade, Serbia \\ ${ }^{5}$ Hospital for Gynecology and Obstetrics, Clinical Hospital Centre \\ "Zemun", Belgrade, Serbia \\ ${ }^{6}$ Clinic of urology, Clinical Center "Dr Dragiša Mišović-Dedinje"- \\ Belgrade, Serbia
}

\section{Abstract}

Screening for Gestational Diabetes (DG) is not carried out thoroughly even in highly developed countries. The aims of this study was to investigate the compliance with local guidelines of screening for GDM in two cities in two different countries, but who share the same GDM screening guidelines and to test differences in those compliances between three different health care centers. Study outcomes were prevalence of GD, prevalence of pregnant women with risk factors for GD and the percentage of women with GD risk factors who have not undergone GD screening. A total of 847 pregnant women were included in the study. The prevalence of GD ranged from $5.29 \%$ to $6.19 \%$. We found no significant differences in the rates of non-compliance with GD screening guidelines, which ranged from $51.85 \%$ to $54.84 \%$.

Keywords: gestational diabetes, audit, compliance with local policy screening

\section{Evaluacija usklađenosti izvršenog skrininga u Trebinju i Beogradu sa vodičima skrininga gestacionog dijabetesa}

Danijela Popadić1, Miroslava Gojnić Dugalić2,3, Milan Perović ${ }^{4,5}$, Bojana Gutić ${ }^{2}$, Tomislav Stefanović ${ }^{5}$, Milica Kovačević 5 , Svetlana Popovac ${ }^{4}$, Jovana Radaković ${ }^{4}$, Uroš Babić 6

${ }^{1}$ Odeljenje za ginekologiju i akušerstvo, Opšta bolnica Trebinje, Trebinje, Bosna i Hercegovina

${ }^{2}$ Klinika za ginekologiju i akušerstvo Kliničkog centra Srbije, Beograd, Srbija

${ }^{3}$ Univerzitet u Beogradu, Medicinski fakultet

${ }^{4}$ Klinike za ginekologiju i akušerstvo „Narodni front“, Beograd, Srbija

${ }^{5}$ Bolnica za ginekologiju i akušerstvo Kliničko-bolnički centar „Zemun“, Beograd, Srbija

${ }^{6}$ Klinika za urologiju, Klinički centar „Dr Dragiša Mišović-Dedinje“ Beograd, Srbija

\section{Apstrakt}

Skrining Gestacionog Dijabetesa (GD) se ne sprovodi striktno čak i u visoko-razvijenim zemljama. Cilj studije je bio da se ispita usklađenost izvođenja skrininga sa vodičima skrininga GD u dva grada koja se nalaze u različitim državama, ali koji se pridržavaju identičnih smernica skrininga, kao i da testira razlike compliances u tri različite medicinske ustanove. Ispitivana je prevalence GD-a, prevalenca trudnica sa faktorima rizika za GD i procenat trudnica sa faktorima rizika koje nisu podvrgnute GD scriningu. Ukupno je 847 trudnica uključeno u studiju. Prevalenca GD-a se kretala od $5.29 \%$ do $6.19 \%$. Nisu nađene značajne razlike u stopama neusklađenosti sprovedenog skrininga sa GD scrining smernicama, a kretale su se od $51.85 \%$ do $54.84 \%$.

Ključne reči: gestational diabetes, audit, compliance with local policy screening

\title{
Introduction
}

Gestational diabetes mellitus (GD) is defined as diabetes first diagnosed in pregnancy and has an important impact on perinatal morbidity and mortality ${ }^{1}$. Screening for GD is routine during pregnancy in many countries in the world. The screening programs are either based on general screening offered to all pregnant women or risk factor based screening stipulated in local clinical guidelines ${ }^{2}$. The 50-gram non-fasting one hour glucose challenge test (GCT), is today the one most widely implemented as a screening test for $\mathrm{GD}^{1}$.

Regardless of the position taken, screening for GD was not carried out thoroughly even in highly developed countries at the end of the $20^{\text {th }}$ century. In the 1990s in Australia, half of the pregnant women were not screened 
for GD during pregnancy despite the recommendation of OGTT screening for all pregnant women ${ }^{3}$. In the last couple of years, the reported observance has been increased and has ranged from $78 \%-92.1 \% 4,5$. Even though the compliance rate is high in these studies, not all qualified women underwent screening as suggested in the local guiding principles. Hence some women with GD may go undetected. Untreated GD or impaired glucose tolerance appear to raise the risk of adverse outcomes such as macrosomia, and cesarean sections $\mathrm{s}^{6,7}$, as well as an increased risk of preterm delivery ${ }^{7}$. Nevertheless, other studies have conflicting results. Still, nowadays even in countries with well developed healthcare systems, despite numerous recommendations for GCT screening stipulated in local guidelines, only one in three pregnant women with risk factors underwent an $\mathrm{GCT}^{2}$.

The aims of this study was to investigate the compliance with local guidelines of screening for GD in two cities in two different countries, but who share the same GD screening guidelines and to test differences in those compliances.

\section{Materials and Methods}

The study was conducted in 3 maternity wards. The first one is in secondary health care center, General Hospital of Trebinje (GHT), with approximately 500 deliveries per year. Trebinje is a town in Bosnia and Herzegovina with almost 40000 inhabitants. The second one is in Clinical Hospital Centre "Zemun" (CHCZ), secondary health care center with almost 1600 births per year. The third one is Clinic for Gynecology and Obstetrics, Clinical center of Serbia (CGOCCS), the tertiary health care center with approximately 6000 deliveries per year. CHCZ and CGOCCS are in Belgrade (the city of approximately 1700000 citizens), Serbia. The study was conducted during one (in CGOCCS), two (in CHCZ) and four months (in GHT). An audit of birth records and the questionnaire enclosed diverse features of medical and obstetric history and the presence of risk factors of the contributed women was undertaken. These items included the presence of risk factors according to the local guidelines of GD screening (Table 1).

\begin{tabular}{|l|c|}
\hline Criteria & cut-off threshold value \\
\hline Family history of diabetes & first degree relative \\
\hline Obesity before pregnancy & BMI $(\mathrm{kg} / \mathrm{m} 2)>30$ \\
\hline Previous pregnancy with GDM & NA \\
\hline Previous child with birth weight $\geq 4000 \mathrm{~g}$ & NA \\
\hline Multiparity & $>3$ deliveries \\
\hline Polyhydramnion & AFI $>200 \mathrm{~mm}$ \\
\hline Accelerated fetal growth & EFW $>90^{\text {th }}$ Percentiles $(\mathrm{g})$ \\
\hline Randomly controlled glycemia at antenatal visits in pregnancy & $\geq 8.0 \mathrm{mmol} / 1$ \\
\hline
\end{tabular}

Table 1. Criteria indicating screening for gestational diabetes mellitus

NA- not applicable; AFI- Amniotic fluid index; EFW- estimated fetal weigh by ultrasound

Study outcomes were total number of deliveries, prevalence of GD, prevalence of pregnant women with risk factors for GD and the percentage of women with GD risk factors who have not undergone GD screening. For the purposes of testing differences in study outcomes between three maternity wards, chi square test was used. 


\section{Results}

The total number of study participants was 847 . The results of study outcomes are presented in the table 2 .

\begin{tabular}{|l|c|c|c|c|}
\hline & GHT & HGOCHCZ & CGOCCS & p \\
\hline Number of deliveries & 149 & 226 & 472 & NR \\
\hline Prevalence of GD & $5.37 \%$ & $6.19 \%$ & $5.29 \%$ & 0.128 \\
\hline Prevalence of women with GD risk factors & $20.81 \%$ & $23.89 \%$ & $20.97 \%$ & 0.06 \\
\hline Frequency of unscreened women with risk for GD & $54.84 \%$ & $51.85 \%$ & $52.52 \%$ & 0.06 \\
\hline
\end{tabular}

Table 2. Results of study outcomes

NR- not relevant for the study

\section{Conclusions}

The prevalence of DM is in agreement with findings of other studies who evaluated similar populations ${ }^{2}$, 3,5 . However, the prevalence was lower than the prevalence of $30 \%$ reported in recent study who addressed the population of pregnant women in Belgrade1. The difference could be explained by different study population. In our population the prevalence was determined in general population, while in the study of Perovic and colleagues, the prevalence is given for the population within high risk patients for GD.

An audit of birth records of three public hospitals (two in secondary and one in tertiary health care center) in two different countries and two different cities was undertaken to determine compliance with the local policies that all women having risk factors for GD should be screened for gestational diabetes mellitus. Study showed that the populations of pregnant women with GD risk factors were screened with similar success, regardless to the setting (secondary or tertiary health care center, big or a small city, different countries). The GD screening was realized in accordance with guidelines in $45.16 \%, 48.15 \%$ and $47.48 \%$, which is much lower than in other studies who reported screening in approximately $80 \%$ of eligible pregnant women ${ }^{4,7}$.

In a non-randomized interventional study, comparing two periods, one before and other after the implementation of the WHO guidelines using reminders, meetings and pre-printed prescription sheets, the proportion of women who were screened significantly from $59.1 \%$ to $80 \%$ of eligible women ${ }^{8}$. Our results are similar to those in pre-implementation period in the mentioned study, indicating the importance of constant reminders and advocacy to the significance of guidelines and policy of GD screening.

Furthermore, the large prospective studies are needed for evaluation of the most common risk factors which are overlooked and neglected. This could be of the importance having in mind that such knowledge would prevent repetition of mistakes or oversights in the selection of patients for GD screening.

\section{Literature}

1. Perović M, Garalejić E, Gojnić M, Arsić B, Pantić I, Jović Bojović D, Fazlagić A, Gardiner H. Sensitivity and specificity of ultrasonography as a screening tool for gestational Diabetes Mellitus. The Journal of Maternal-Fetal \& Neonatal Medicine 2012; 25 (8): 1348-1353.

2. Persson M, Winkvist A, Mogren I. Surprisingly low compliance to local guidelines for risk factor based screening for gestational diabetes mellitus - A population-based study. BMC Pregnancy Childbirth 2009;9:53.

3. Moses RG, Colagiuri S. The extent of undiagnosed gestational diabetes mellitus in New South Wales. Med J Aust. 1997; 167(1): 14-6.

4. Ruengkhachorn I, Sunsaneevithayakul P, Boriboonhirunsarna D. Non-compliance to clinical practice guideline for screening of gestational diabetes mellitus in Siriraj Hospital. J Med Assoc Thai. 2006; 89 (6): 767-72. 
5. ÖStlund I, Hanson U. Occurrence of gestational diabetes mellitus and the value of different screening indicators for the oral glucose tolerance test. Acta Obstetricia et Gynecologica Scandinavica 2003; 82: 103-108.

6. Langer O, Yogev Y, Most O, Xenakis E. Gestational diabetes: the consequences of not treating. American Journal of Obstetrics \& Gynecology 2005; 192 (4): 989-997.

7. Ostlund I, Hanson U, Bjorklund A, Hjertberg R, Eva N, Nordlander E, Marja-Liisa S, Wager J. Maternal and Fetal Outcomes if Gestational Impaired Glucose Tolerance Is Not Treated. Diabetes Care 2003; 26 (7): $2107-11$.

8. Gayet-Ageron A, Poncet B, Guerre P, Rocher L, Dureau-Drevard E, Colin C, Orgiazzi J, Berland M, Touzet S. Specific information about the WHO guidelines for gestational diabetes screening improves clinical practices. Journal of Evaluation in Clinical Practice 2008; 14: 36-42.

Author for correspondence: Dr Danijela Popadic Address: Vojislava Koraca 7, Trebinje, Bosnia and Herzegovina E-mail: danijelapopadic98@gmail.com 